\title{
ÜNIVERSITTE ÖĞRENCILERİNIN
}

\begin{tabular}{|c|c|}
\hline NOMOFOBİ DÜZEYİ İLE ÖZNEL İYİ & $\begin{array}{c}\text { Hacettepe } \\
\text { Unniversitesi iktisadi }\end{array}$ \\
\hline OLMA DURUMLARI ARASINDAKİ & $\begin{array}{l}\text { ve idari Bilimler } \\
\text { Fakültesi Dergisi }\end{array}$ \\
\hline İLİŞKİNİN BELİRLENMES & $\begin{array}{l}\text { Cilt 37, Sayı 4, } 2019 \\
\text { s. 651-674 }\end{array}$ \\
\hline
\end{tabular}

\section{ARDAHAN ÖRNEĞİ}

\author{
Ali Çağlar GÜLLÜCE \\ Dr.Öğr. Üyesi, Atatürk Üniversitesi \\ Açıköğretim Fakültesi \\ İșletme Bölümü \\ achaglar@atauni.edu.tr

\section{Erdoğan KAYGIN} \\ Doç.Dr., Kafkas Üniversitesi \\ İktisadi ve İdari Bilimler Fakültesi \\ İşletme Bölümü \\ erdogankaygin@hotmail.com

\section{Nihat Emre BÖREKÇİ} \\ Öğr.Gör., Ardahan Üniversitesi \\ Ardahan Sosyal Bilimler Meslek \\ Yüksekokulu \\ nihatemeborekci@ardahan.edu.tr
}

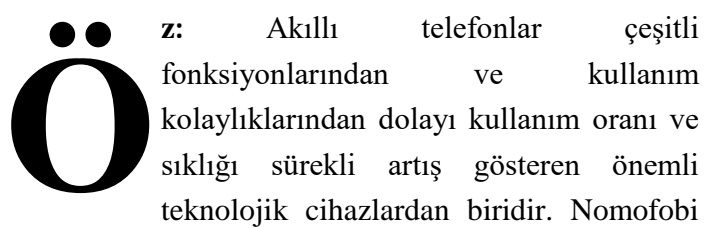
diğer bir deyişle akıllı telefondan uzak kalma korkusu sürekli gelişen teknoloji ile birlikte son zamanlarda ortaya çıkan bir rahatsızlıktır. Mevcut çalışmada, Ardahan Üniversitesi'nde 2017-2018 öğretim y1lı güz döneminde öğrenim gören öğrencilerin $(\mathrm{N}=395)$ nomofobi düzeylerinin öznel iyi olma (mutluluk) ile ilişkisi; Oxford Mutluluk Ölçeği-Kısa Formu ile Nomofobi Ölçeği (NMP-Q) kullanılarak incelenmiştir. Elde edilen veriler, betimsel istatistikler, korelasyon analizi ve ANOVA ile test edilmiştir. Analiz sonuçlarına göre, öğrencilerin nomofobi düzeylerinin ortalamanın biraz üzerinde, mutluluk düzeylerinin ise ortalamanın üzerinde olduğu belirlenmiştir. Nomofobi alt boyutu olarak en yüksek ortalama iletişime geçememe korkusu olarak tespit edilmiştir. Öğrencilerin bağlantıyı kaybetme korkuları ile mutluluk düzeyleri arasında ise ters yönlü bir ilişki bulunmuştur. Nomofobinin en çok genç bireylerde görüldüğü, kadınların erkeklere göre daha fazla nomofobik oldukları tespit edilmiştir.

Anahtar Sözcükler: Akall telefon, bağımlılık, nomofobi, öznel iyi olma, mutluluk, üniversite ögrencileri 



\section{DETERMINATION OF THE}

\begin{tabular}{|c|c|}
\hline RELATIONSHIP BETWEEN THE & $\begin{array}{l}\text { Hacettepe University } \\
\text { Journal of Economics } \\
\text { and Administrative }\end{array}$ \\
\hline LEVEL OF NOMOPHOBIA AND & $\begin{array}{l}\text { Sciences } \\
\text { Vol. } 37, \text { Issue 4, } 2019\end{array}$ \\
\hline
\end{tabular}

SUBJECTIVE WELL-BEING OF

pp. 651-674

\section{UNIVERSITY STUDENTS: ARDAHAN CASE}

\author{
Ali Çağlar GÜLLÜCE \\ Assist.Prof.Dr., Atatürk University \\ Faculty of Open University \\ Department of Business Administration \\ achaglar@atauni.edu.tr

\section{Erdoğan KAYGIN} \\ Assoc.Prof.Dr., Kafkas University \\ Faculty of Economics and \\ Administrative Sciences \\ Department of Business Administration \\ erdogankaygin@hotmail.com
}

\section{Nihat Emre BOREKCI}

Lecturer, Ardahan University

Ardahan Social Sciences Vocational

School

nihatemreborekci@ardahan.edu.tr bstract: Smart phones are one of the
most important technological devices
with increasing usage rate and
frequency due to various functions and ease of use. Nomophobia, in other words, the fear of being away from the smartphone is a recent discomfort with the constantly developing technology. In the present study, the relationship between nomophobia levels and subjective well-being (happiness) of Ardahan University students $(\mathrm{N}=395)$ in the fall semester of 2017-2018 is investigated using Oxford Happiness Scale-Short Form and Nomophobia Scale (NMP-Q). The obtained data are tested with descriptive statistics, correlation analysis and ANOVA. According to the analysis results; It is determined that the students' nomophobia levels are slightly above average and their happiness levels are above average. Fear of not being able to communicate has been identified as a sub-dimension of Nomophobia with the highest average. An inverse relationship is found between the fear of losing connection and the levels of happiness of the students. It has been determined that nomophobia is mostly seen in young individuals and women are more nomophobic than men.

Keywords: Smart phone, dependency, nomophobi, subjective well-being, happiness, university students. 


\section{GíRiş}

Hızla gelişen teknoloji günlük faaliyetlerimizi ve alışkanlıklarımızı büyük ölçüde etkilemektedir. Bu etkileşimin sebeplerinden biri olan akıllı telefonlar ise bilgi ve iletişim teknolojisinin en hızlı gelişim gösteren araçlarından biridir ve çeşitli fonksiyonları ile son döneme damgasını vurmaktadır (Argumosa-Villar vd., 2017: 127). Akıllı telefonlar, ulaşılabilirliği ve taşıma kolaylığı ile günlük hayatın bazı gereksinimlerini karşılamada önemli bir yere sahiptir (Kang, Jung, 2014: 376). Günümüzde kullanım sıklığı giderek artan bu cihazlar, kablosuz bir şekilde mesajlaşma, arama gibi diğer telefonların sunduğu hizmetlere ek olarak; internet vasıtasıyla elektronik posta gönderme, alışveriş, sosyal ağlara erişim, randevuları zamanlama, eğlence ve oyunlar gibi pek çok avantaj sağlamaktadır. Bunlar gibi çeşitli özelliklerden dolayı insanlar, özellikle de üniversite öğrencileri cep telefonlarını eskiye oranla daha fazla kullanır hale gelmişlerdir (Park $v d$., 2013: 1764; Lee, 2014: 1). Türkiye İstatistik Kurumu'nun (TÜIK, 2016) hanehalkı bilişim teknolojileri kullanım araştırması raporuna göre, 2016 yılı Nisan ayında (16-74 yaş aralığı baz alınarak) internet kullanım oranı \%61,2'ye ulaşırken Türkiye'deki hanelerin $\% 96,9$ 'unda cep telefonu veya akıllı telefon bulunduğu rapor edilmiştir.

Akıllı telefonlar, adeta insanların bir parçası haline gelmesiyle bazı kolaylıklar sunmakla birlikte olumsuz etkilere de sebep olabilmektedir. Bunlar arasında; sosyal izolasyon, bu cihazları satın alıp kullanmaya yönelik daha büyük borçlar ve bazı sosyal problemler sayılabilmektedir. Elektromanyetik alan radyasyonu, araba kazaları, ayrıca yeni teknolojik cihazları kullanamama korkusu ile ilişkili kaygı gibi fiziksel ve psikolojik bazı problemlere neden olabilmektedir (Pavitra $v d$., 2015: 340). Diğer taraftan, bu teknolojik ürünlerin bağımlılık yapabileceği de belirtilmiştir (Beranuy $v d$., 2009: 1182; Salehan, Negahban, 2013: 2633). Bu ve benzeri nedenlerden dolayı insan yaşamının bir parçası haline gelerek onları etkilemesi dolayısıyla araştırmada nomofobi ile insanların karşılaştıkları olaylar karşısında göstermiş oldukları duygusal cevapları ve hayatlarına dair değerlendirmelerini ifade eden öznel iyi oluş arasındaki ilişkinin belirlenmesi amaçlanmıştır.

\section{KAVRAMSAL ÇERÇEVE}

\subsection{Nomofobi}

Akıllı telefon bağımlılığı sonucu "nomofobi" adı verilen bir rahatsızlık ortaya çıkmıştır. Nomofobi terimi cep telefonuna erişememe veya ulaşılamama korkusu olarak tanımlanmaktadır. Diğer bir deyişle; cep telefonu ve/veya bilgisayarı sıklıkla kullanan bireylerde bir veya başka herhangi bir sanal iletişim cihazının bulunmaması nedeniyle ortaya çıkan rahatsızlığ veya endişeyi ifade etmektedir (King $v d$., 2013: 141). Bu rahatsızlık ilk olarak 2008'de İngiltere Posta Ofisi tarafindan cep telefonu 
kullanıcılarının taşıdığı kaygıları ölçmek için yapılan bir araştırma sonucunda ortaya çıkmışıtır. 2100 kişiye uygulanan çalışmanın sonucunda bireylerin \%53 oranında nomofobik düzeyde oldukları ve erkeklerin kadınlara göre nomofobiye yakalanma olasılığının daha fazla olduğu rapor edilmiştir (Mail Online, 2008).

Nomofobi, insanlarla mobil bilgi ve iletişim teknolojileri (özellikle akıllı telefonlar) arasındaki etkileşimin bir sonucu olarak hayatımıza girmekte ve yeni dönem fobisi olarak kabul edilmektedir (Uysal vd., 2016: 3; King $v d$., 2013: 141). King $v d$.'nin (2010) raporu, nomofobi hakkındaki ilk araştırmadır. Rapor, nomofobiyi modern dünyanın bir bozukluğu olarak nitelendirmektedir. Benzer şekilde Dixit $v d$. nomofobiyi "modern çağın ortaya çıkmakta olan bir problemi"” olarak görmektedir (Arpaci, 2017: 2). Diğer taraftan, cep telefonu ile iletişim kurma yoğunluğunun genç bireyler arasında oldukça fazla olduğu ifade edilmektedir (Dempsey $v d$., 2009: 962).

\subsection{Nomofobinin Etkileri}

Nomofobi, pili şarjlı tutmak için her zaman bir şarj cihazı taşıma, şebeke kapsamı eksikliği nedeniyle telefonu kullanamayacağını düşündüğünde endişeli hissetme gibi farklı semptomlar oluşturan bir kaygı bozukluğudur. Nomofobiye sahip olan kişiler ayrıca cihazın kullanımının (tiyatrolar, sinemalar vb.) yasaklandığı yerlerden ve durumlardan kaçınmaya çalışmakta ve mesajların veya çağrıların alınıp alınmadığını görmek için telefonun ekranına sürekli bakmaktadır (González-Cabrera $v d ., 2017$ : 138). Toplumsal durumlarda nomofobi, bireyin günlük yaşamında aşırı anksiyete veya akut girişimlere neden olabileceği gibi, kişilerarası iletişim, performans ya da her ikisini de kapsayan yoğun endişe duyma halini beraberinde getirmektedir. Bunun için; önceden var olan bir zihinsel bozukluğun göstergesi olabilen bazı belirtilerin araştırılması, teşhisin konulması ve ilaç ve/veya psikoterapi ile tedavi edilmesi gerekmektedir (King $v d$., 2013: 141). Potansiyel adaylarda önceden var olan zihinsel rahatsızlıklardan ötürü sosyal fobi ya da sosyal kaygı bozukluğu ve panik bozukluk da dahil olmak üzere bazı semptomların ortaya çıkması olası görülmektedir (Uysal $v d$., 2016: 3).

Nomofobiye yakalanmış bireylerde akıllı telefonlardan ayrılmanın bir sonucu olarak kalp atış hızı, kan basıncı, kaygı durumlarında artış (Clayton $v d ., 2015: 1)$ ve alışılmış sanal iletişimi sağlayan bir cihazın bulunmamasından kaynaklanan panik duygularının oluştuğu saptanmıştır (King $v d$., 2013: 141). Nomofobik bireyler sık kullanımdan dolayı bakma takıntısına, takıntılı kullanma dolayısıyla endişe seviyesinde artmaya ve konsantrasyon bozukluğuna maruz kalmaktadırlar (Minaz, Çetinkaya Bozkurt, 2017: 271). Bu bireylerin sürekli mesaj veya çağrı olup olmadığını kontrol etmek, telefonu 24 saat açık bırakmak, yatağa akıllı telefon ile girmek (Bragazzi, Pente, 2014: 157) gibi alışkanlıklarının olduğu ve bunlardan 
kaynaklı boyun ağrısı (Haug vd., 2015: 299), göz ve uyku bozukluğu (Kwon vd., 2013: 6) gibi sağlık sorunlarına yol açtığı bilinmektedir.

Yalnızlık hissi, depresyon, yaşam beklentisinde ve fiziksel aktivitelerde azalma, düşük öz saygı ve sosyal medya nedeniyle yüz yüze iletişimin azalması ile sosyal yönlerde azalma gibi durumlar nomofobik bireylerde sıklıkla görülen diğer sorunlar arasinda gösterilmektedir (Erdem $v d$., 2016: 924). Özellikle telefonda harcanan zamanın başkaları ile kalite iletişimi engellediği ve böylece aile ve arkadaşlarla sosyalleşmenin vermiş olduğu sağlık yararlarını ortadan kaldırdığı için Amerikan pediatri Akademisi tarafından özellikle çocukların ve ergenlerin sosyal medya ve telefonla harcadıkları zamanları sınırlandırmalarını önermektedir (Taylor, Bazarova, 2018: 86). Bunun dışında, bireyler herkesle rahat iletişimde bulunabildiklerinden yanlış kişilerle tanışıp sağlıksız ve yasal olmayan ortamlara çekilme, casus yazılımlar nedeniyle insanların özel hayatına müdahale edilebilmesi ve şifrelerinin alınabilmesi gibi değişik sorunların ortaya çıkmasına neden olduğu gözlemlenmektedir (Minaz, Çetinkaya Bozkurt, 2017: 271). Hollender'e göre nomofobi, obsesif-kompulsif bozukluğa benzemektedir fakat nomofobide kişi keyif almak adına takıntılı davranışlar sergilediğinden obsesif kompulsif bozukluktaki gibi endişe ya da bir dürtüyü ortadan kaldırmak için zorlayıcı davranışlar sergilenmediğinden farklı olgular olarak düşünülmektedir (Şar, Işıklar, 2012: 266).

\section{3. Öznel İyi Olma (Mutluluk)}

Eski zamanlardan günümüze kadar insanoğlunu neyin mutlu ettiği ile ilgili sorgulamalara felsefe ve din başta üzere pek çok alanda cevap verilmeye çalışılmışıtır. Özellikle psikoloji biliminin gelişimi insanı mutlu eden faktörlerin keşfedilmesine yönelik çabalara ivme kazandırmıştır (İlhan, Özbay, 2010: 109).

Günlük yaşamda mutluluk kavramı olarak da kullanılabilen (Dost, 2005: 104) ve insanların yaşamları hakkındaki hem bilişsel hem de duygusal değerlendirmelerini kapsayan öznel iyi oluş (Diener, 2000: 34), olumlu duyguların olumsuz duygulara oranla daha sık yaşanması durumunu ifade eder (Süler, 2016: 29). Öznel iyi oluş, bireyin olaylara verdiği duygusal tepkilerin bir sonucudur (Doğan, 2013: 56) ve genellikle gülümseme ya da gülme ile ifade edilir (Özgün $v d$., 2017: 86). Türk Dil Kurumu'na (2018) göre mutluluk "Bütün özlemlere eksiksiz ve sürekli olarak ulaşılmaktan duyulan kıvanç durumu" olarak tanımlamaktadır. Kısaca mutluluk bireyin hayattan zevk alması ve mükemmel hissetmesi olarak tanımlanabilir (Özgün $v d ., 2017: 86)$.

Bireyin olumlu duyguları olumsuz duygulardan daha sık yaşaması, yaşam alanların tümünden doyum alması mutluluğun göstergeleri olarak belirtilmektedir 
(Demir, Murat, 2017: 350-351). Öznel olarak iyi (mutlu) olan insanlar dünyayı daha güvenli algılar, daha kolay işbirliği yapar, daha hoşgörülü olur ve özgüvenleri daha yüksektir. Diğer insanlara göre sosyal bağları daha güçlüdür (Akyüz vd., 2018: 1088), yaşamlarını yönlendirmede kendilerini daha özgüvenli hissederler.

\subsection{Nomofobi ve Öznel İyi Olma (Mutluluk) İlişsisi}

Akıllı telefonların yüz yüze iletişim kanalını sınırlamadaki mevcut potansiyeli sayesinde sosyalleşme gün geçtikçe azalmaktadır ve bu durum insanları akıllı telefonlarından ayrılamaz hale getirerek yalnız kalmalarına sebep olmaktadır. Bu yalnızlaşma durumunda internet, sosyal ağ ve akıllı telefon bağımlılı̆ıının payı olduğu ve yapılan çalışmalarla bunların öznel iyi oluş, stres ve depresyonun ilişkilendirildiği belirtilmiştir. Örneğin Kore'de yapılan bazı çalışmalarda internet bağımlılığının depresif semptomlarda artı̧̧a ve öznel mutluluk seviyesinde azalışa neden olduğu tespit edilirken (Ha, Hwang, 2014; Yoo vd., 2014), akıllı telefon bağımlılı̆ıının da depresyon (Kim $v d$., 2015) ve öznel mutluluk seviyesinde azalmaya (Süler, 2016) neden olduğu rapor edilmiştir. Yapılan bir diğer çalışmada, problemli telefon kullanımının kişide stres ve depresyon seviyesini artırdığı (Augner, Hacker, 2012), cep telefonu kullanımının artması ile kişinin kendine güvensiz, sosyal açıdan uyumsuz olma, obsesif, bağımlı ya da antisosyal özellikler taşıma, sık moral bozukluğu, anksiyete yaşama ile iliş̧kili bulunmuştur (Sevi $v d$. ., 2014).

Nomofobi ile mutluluk arasındaki ilişkiye dönük araştırmaların dışında literatürde, nomofobi ile demografik özellikler ve cep telefonu kullanımına ilişkin bazı değişkenlere göre de çalışmalar vardır. Örneğin üniversite öğrencileri ve kamu çalışanlarına yapılan bir çalışmada öğrencilerinin \%54'inin, ulaştırma sektörü çalışanlarının \%47'sinin nomofobik olduğu, nomofobinin kadınlarda daha yüksek olduğu, yaş ile nomofobi arasında ters yönlü ve anlamlı bir ilişki olduğu, günlük akıllı telefon kullanma süresi ile nomofobi arasında pozitif ve anlamlı bir ilişki bulunduğu tespit edilmiştir (Erdem $v d$., 2017). Başka bir çalışmada nomofobiye yatkın bireylerin, gün içerisinde sıklıkla telefonlarını kontrol ettiklerini, yanlarında şarj aleti taşıdıklarını, gece telefonlarını kapatmadıklarını, yatmadan önce yatakta telefonlarıyla zaman geçirdiklerini ve uyanır uyanmaz telefonlarını kontrol ettiklerini ortaya çıkarmıştır (Akıllı, Gezgin, 2016). Öğretmen adaylarına yapılan başka bir çalışmada kadın öğrencilerin, erkek öğrencilere göre daha nomofobik olduğu görülmüş, ayrıca yaş arttıkça nomofobinin azaldığı, fakat akıllı telefon kullanma süresi arttıkça nomofobinin arttı̆̆ı görülmüştür (Gezgin $v d$., 2017). Abraham $v d$. (2014) öğrenciler üzerine yaptığı çalışmada da benzer sonuçlar bulunmuştur. Çalışma sonuçlarına göre Nomofobi düzeyi ile yaş, cinsiyet, aylık gelir, günde ortalama cep telefonu kullanım süresi, gün içerisinde cep telefonunu kontrol etme sayısı ve cep telefonu şarj aleti taşıyanların anlamlı bir ilişki içerisinde olduğu saptanmıştır. Yıldırım vd. (2016) ise 
öğrenciler üzerine yaptığı çalışmada öğrencilerin en büyük korkularının nomofobi alt boyutu olan iletişim ve bilgi erişimi ile ilgili olduğu tespit edilmiştir.

Nomofobinin demografik faktörlere göre değişip değişmediğini araştıran çalışmaların yanında mutluluğun cinsiyete göre farklılaşıp farklılaşmadığını inceleyen çalışmalar da yapılmıştır. Örneğin, Diener ve Diener (1995) 31 ülkede 13.118 kişi üzerinde yaptığı çalışmasında kişinin erkek veya kadın olması ile mutlu olması arasında anlamlı bir fark bulamamıştır. Bunun aksine Wood $v d$. (1989) tarafından 1963-1985 yılları arasındaki 93 çalışmanın incelendiği meta analizde mutluluk düzeylerini kadınlarda erkeklere göre daha fazla olduğu tespit edilmiştir.

Bu bilgiler ışığında aşağıdaki hipotezler geliştirilmiştir.

$\mathrm{H}_{1}$ : Öğrencilerin nomofobi durumları ile mutluluk hisleri arasında negatif yönlü bir ilişki vardır.

$\mathrm{H}_{2}$ : Öğrencilerin nomofobi alt boyutları ile mutluluk hisleri arasında negatif yönlü bir ilişki vardır.

$\mathrm{H}_{2 \mathrm{a}}$ : Öğrencilerin nomofobi alt boyutlarından olan "Bilgiye Erişememe" ile mutluluk hisleri arasında negatif yönlü bir ilişki vardır.

$\mathrm{H}_{2 b \text { : }}$ Öğrencilerin nomofobi alt boyutlarından olan "Bağlantıyı Kaybetme” ile mutluluk hisleri arasında negatif yönlü bir ilişki vardır.

$\mathrm{H}_{2 \mathrm{c}}$ Öğrencilerin nomofobi alt boyutlarından olan "İletişime Geçememe" ile mutluluk hisleri arasında negatif yönlü bir ilişki vardır.

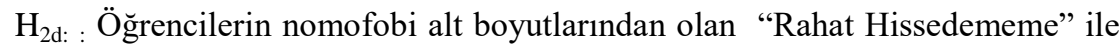
mutluluk hisleri arasında negatif yönlü bir ilişki vardır.

$\mathrm{H}_{3:}$ Öğrencilerin demografik faktörleri ve telefon kullanımına ilişkin alıskanlıkları arasında farklılıklar vardır.

\section{METODOLOJI}

\subsection{Araştırmanın Amacı}

$\mathrm{Bu}$ çalışmada Üniversite öğrencilerinin Nomofobi (cep telefonundan uzak kalma korkusu) düzeyleri ile mutluluk hisleri arasındaki ilişkini belirlenmesi amaçlanmıştır. Ayrıca öğrencilerin demografik faktörleri ve telefon kullanımına ilişkin alışkanlıklar arasında farklılıkların olup olmadığının belirlenmesi amaçlanmıştır. 


\subsection{Araştırmanın Kapsamı ve Yöntemi}

$\mathrm{Bu}$ araştırmanın ana kütlesini Ardahan Üniversitesi’nde okuyan öğrenciler oluşturmaktadır. Araştırma kapsamında 420 anket dağıtılmış, eksik olanlar ayrıldıktan sonra 395 anket üzerinden analiz yapılmıştır.

Araştırma için kullanılan anket üç bölümden oluşmaktadır. Birinci bölüm öğrencilerin demografik özellikleri içeren sorularla beraber cep telefonu kullanımı ile ilgili sorular bulunmaktadır. Araştırmanın ikinci kısmında öğrencilerin mutluluk düzeylerini ölçmek amacıyla Oxford Mutluluk Ölçeği - Kısa Formu uygulanmıştır. Ölçek $v d$. (2002) tarafindan geliştirilmiş olup ölçeğin Türkçeye uyarlanması Doğan ve Çötok (2011) tarafından yapılmıştır. Ölçek yedi maddeden ve tek bir boyuttan oluşmaktadır. Ölçeğin 1. ve 7. soruları tersten kodlanmıştır. Ölçeğin güvenirliği (cronbach alfa) .72 olarak bulunmuştur. Araştırmanın üçüncü kısmında ise öğrencilerin nomofobi düzeylerini belirlemek amacıyla Yildirim ve Correia (2015) tarafından geliştirilen ve Yildirim $v d$. (2015) tarafindan Türkçeye uyarlanan Nomofobi Ölçeği (NMP-Q) kullanılmıştır. Ölçek 20 maddeden meydana gelmektedir. Ölçeğin "Çevrimiçi Olamama", "İletişimi Kaybetme", "Cihazdan Yoksunluk" ve "Bilgiye Ulaşamama " olmak üzere toplam dört alt boyutu vardır. Ölçekte veriler 5'li Likert (1: Kesinlikle Katılmıyorum, 2: Katılmıyorum, 3: Kararsızım, 4: Katıliyorum, 5: Kesinlikle Katılıyorum) olarak alınmıştır. Ölçeğin güvenirliği (cronbach alfa) .88 olarak bulunmuştur.

\section{3. Ölçeklerin Geçerlilikleri ve Ortalamaları}

Nomofobi ölçeğinin geçerliliğini belirlemek amacıyla Keşfedici Faktör Analizi (KFA) yapılmıştır. KFA yapılırken veriler varimax yöntemiyle döndürülerek analizlere dâhil edilmiştir. Yapılan KFA sonucunda verilerin Yıldırım ve Correira (2015)'nın ve Yıldırım $v d$. (2015)'nin yaptığı çalışmalara benzer şekilde dört faktör altında toplandığı görülmüş̧ür. KFA sonuçlarının ayrıntısı ve maddelerin ortalama puan ve standart sapmalarını içeren ayrıntılı madde analizi Tablo-1'de sunulmuştur. 
Tablo 1. Keşfedici Faktör Analizi, Maddelerin Ortalaması ve Standart Sapması

\begin{tabular}{|c|c|c|c|c|c|c|c|}
\hline & Sorular & 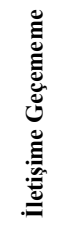 & 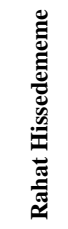 & 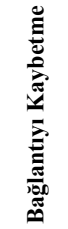 & 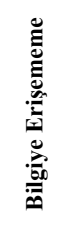 & 莺 & $\infty$ \\
\hline M13 & $\begin{array}{l}\text { Ailemle ve/veya arkadaşlarımla iletişim halinde } \\
\text { olamadığım için endişelenirim. }\end{array}$ & .816 & & & & 3.66 & 1.19 \\
\hline M11 & $\begin{array}{l}\text { Ailem ve/veya arkadaşlarım bana ulaşamayacakları için } \\
\text { endişelenirim }\end{array}$ & .795 & & & & 3.75 & 1.17 \\
\hline M10 & $\begin{array}{l}\text { Ailemle ve/veya arkadaşlarımla hemen } \text { iletişim } \\
\text { kuramayacağım için kaygı duyarım. }\end{array}$ & .766 & & & & 3.57 & 1.24 \\
\hline M15 & $\begin{array}{l}\text { Ailem ve arkadaşlarımla olan bağlantım kesileceği için } \\
\text { kendimi huzursuz hissederim. }\end{array}$ & .683 & & & & 3.49 & 1.18 \\
\hline M12 & $\begin{array}{l}\text { Gelen aramaları ve mesajları alamayacağım için kendimi } \\
\text { huzursuz hissederim. }\end{array}$ & .624 & & & & 3.39 & 1.24 \\
\hline M14 & $\begin{array}{l}\text { Birinin bana ulaşmaya çalışıp çalışmadığını bilemediğim } \\
\text { için gerilirim. }\end{array}$ & .526 & & & & 3.14 & 1.22 \\
\hline M18 & $\begin{array}{l}\text { Bağlantılarımdan ve çevrimiçi ağlardan gelen güncelleme } \\
\text { bildirimlerini takip edemediğim için kendimi tuhaf } \\
\text { hissederim. }\end{array}$ & & .831 & & & 2.48 & 1.22 \\
\hline M17 & $\begin{array}{l}\text { Sosyal medya ve diğer çevrimiçi ağlarda güncel } \\
\text { kalamadığım için rahatsızlık duyarım. }\end{array}$ & & .763 & & & 2.54 & 1.28 \\
\hline M19 & $\begin{array}{l}\text { Elektronik postalarımı kontrol edemediğim için kendimi } \\
\text { huzursuz hissederim }\end{array}$ & & .760 & & & 2.50 & 1.21 \\
\hline M16 & Çevrimiçi kimliğinden kopacağım için gergin olurum. & & .707 & & & 2.43 & 1.18 \\
\hline M20 & $\begin{array}{l}\text { Ne yapacağımı bilemiyor olacağımdan, kendimi tuhaf } \\
\text { hissederim. }\end{array}$ & & .584 & & & 2.88 & 1.33 \\
\hline M9 & $\begin{array}{l}\text { Akıllı telefonuma bir süre bakamadıysam, bakmak için } \\
\text { güçlü bir istek hissederim. }\end{array}$ & & & .704 & & 3.32 & 1.29 \\
\hline M7 & $\begin{array}{lllll}\text { Telefonum } & \text { çekmediğinde } & \text { veya } & \text { kablosuz } & \text { Internet } \\
\text { bağlantısına } & \text { erişemediğimde } & \text { sürekli } & \text { olarak sinyal olup } \\
\text { olmadığını } & \text { veya kablosuz } & \text { erişim } & \text { bağlantısı bulup } \\
\text { bulamayacağımı kontrol ederim. } & & \end{array}$ & & & .704 & & 3.32 & 1.31 \\
\hline M5 & Akıllı telefonumun şarjının bitmesinden korkarım. & & & .671 & & 3.04 & 1.43 \\
\hline M6 & $\begin{array}{l}\text { Kontörüm (TL kredim) bittiğinde veya aylık kota sınırımı } \\
\text { aştığımda paniğe kapılırım. }\end{array}$ & & & .622 & & 2.74 & 1.41 \\
\hline M8 & $\begin{array}{l}\text { Akıllı telefonumu kullanamadığımda, bir yerlerde mahsur } \\
\text { kalacağımdan korkarım. }\end{array}$ & & & .591 & & 2.57 & 1.29 \\
\hline M1 & $\begin{array}{l}\text { Akıllı telefonumdan sürekli olarak bilgiye erişemediğimde } \\
\text { kendimi rahatsız hissederim. }\end{array}$ & & & & .812 & 3.14 & 1.26 \\
\hline M2 & $\begin{array}{l}\text { Akıllı telefonumdan istediğim her an bilgiye } \\
\text { bakamadığımda canım sıkılır. }\end{array}$ & & & & .800 & 3.29 & 1.23 \\
\hline M3 & $\begin{array}{l}\text { Haberlere (örneğin neler olup bittiğine, hava durumuna ve } \\
\text { diğer haberlere) akıllı telefonumdan ulaşamamak beni } \\
\text { huzursuz yapar. }\end{array}$ & & & & .691 & 3.11 & 1.29 \\
\hline M4 & $\begin{array}{l}\text { Akıllı telefonumu ve telefonumun özelliklerini istediğim } \\
\text { her an kullanamadığımda rahatsız olurum. }\end{array}$ & & & & .476 & 3.10 & 1.26 \\
\hline
\end{tabular}




\section{ARAŞTIRMANIN BULGULARI}

\subsection{Demografik Özelliklere İlişkin Bulgular}

Çalışma kapsamında 395 öğrenciye yapılan anket formunun birinci bölümü olan demografik özellikleri Tablo2'de verilmektedir.

Tablo 2. Demografik Özellikler

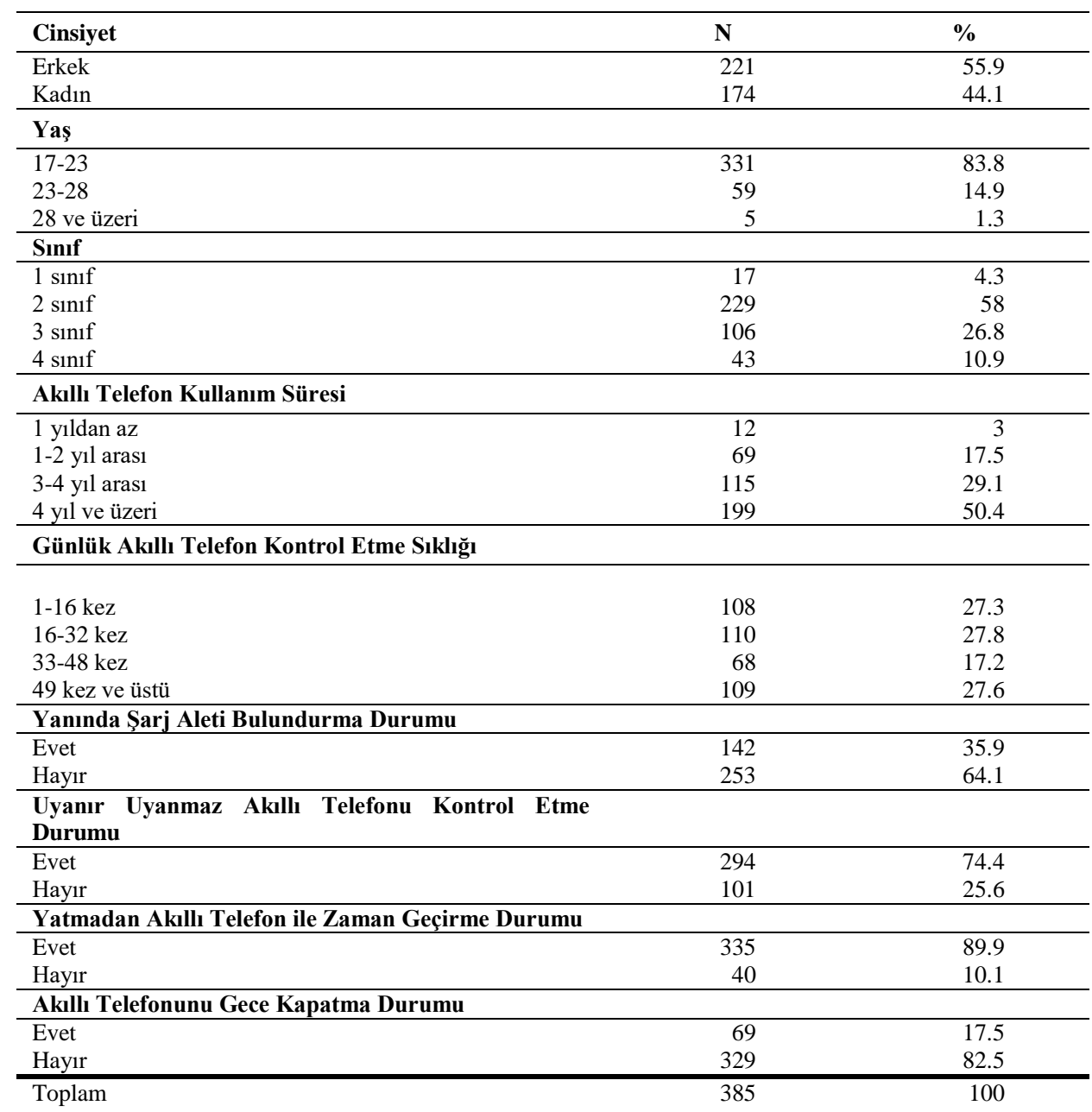

Tablo 2'ye göre öğrencilerin \%55.9'u erkek ( $\mathrm{N}=221)$, \%44.1'i kadındır (N=174). Katılımcıların \%83.8'i 17-23 yaş aralığında olup \%16,2'si 23 yaş ve üzerindedir. Katılımcıların büyük çoğunluğu 2.sınıf (\%58) olup, nerdeyse yarısının (\%50.4) 4 yıldan fazladır akıllı telefonu bulunmaktadır. Öğrencilerin \%27.3'ü günde 
1-16 kez, \%27.8'i günde 16-32 kez, \%17.2'si günde 33-48 kez ve \%27.6's1 da günde $49 \mathrm{kez}$ ve üzeri telefonunu kontrol etmektedir. Katılımcıların \%64.1'i yanında şarj aleti taşımazken, \%74.4'ü uyanır uyanmaz telefonunu kontrol etmektedir. Aynı şekilde katılımcıların \%89.9'u yatmadan önce telefonuyla zaman geçirmekte ve bu katılımcıların çoğu (\%82.5) telefonunu gece kapatmamaktadır.

\subsection{Ortalama ve Standart Sapmaya İliş̧kin Bulgular}

Mutluluk, nomofobi ve alt boyutları düzeylerinin belirlenmesi için ortalamaları belirlenmiştir. Sonuçlar tablolarda sunulmuştur. Ortalamaların değerlendirilmesinde aşağıda ifade edilen değerler sınır olarak kabul edilmiştir.

\section{Tablo 3. Sinır Kabul Edilen Değerler}

\begin{tabular}{|l|l|}
\hline Değer & Açıklama \\
\hline $1.00-1.79$ & Çok Düşük \\
\hline $1.80-2.59$ & Düşük \\
\hline $2.60-3.39$ & Orta \\
\hline $3.40-4.19$ & Yüksek \\
\hline $4.20-5.00$ & Çok Yüksek \\
\hline
\end{tabular}

Ortalamaların değerlendirilmesinde kabul edilen sınırlar göz önünde tutulduğunda araştırmaya katılanların mutluluk düzeylerinin yüksek olduğu görülmüştür. Nomofobi düzeyinin 3.07 ortalama ile orta düzeyde olduğu ortaya çıkarılmıştır. Nomofobinin alt boyutları olan Bilgiye Erişememe, Bağlantıyı Kaybetme'nin de orta düzeyde olduğu ortaya çıkarılmıştır. Rahat Hissedememe boyutu düşük düzeyde ve İletişime Geçememe boyutu ise yüksek düzeydedir.

Tablo 4. Mutluluk ve Nomofobi ile Alt Boyutları Ortalama ve Standart Sapma Değerleri

\begin{tabular}{|l|c|c|}
\hline Boyut & Ortalama & Standart Sapma \\
\hline 1.Mutluluk & 3.41 & 0.75 \\
\hline 2.Bilgiye Erişememe & 3.16 & 0.93 \\
\hline 3.Bağlantıyı Kaybetme & 3.00 & 0.97 \\
\hline 4.İletişime Geçememe & 3.45 & 0.90 \\
\hline 5.Rahat Hissedememe & 2.57 & 0.95 \\
\hline 6.Nomofobi & 3.07 & 0.70 \\
\hline
\end{tabular}

\subsection{Korelasyon Analizine İlişskin Bulgular}

Araştırma değişkenleri arasındaki ilişki incelendiğinde mutluluk ile nomofobi ve nomofobi alt boyutlarından sadece bağlantıyı kaybetme korkusu ile ters yönde bir ilişki olduğu görülmektedir. Bu ilişkinin çok düşük düzeyde olduğu görülmektedir. 
Tablo 5. Boyutlar Arası Korelasyonlar ve Betimleyici İstatistikler

\begin{tabular}{|l|r|r|r|r|r|r|r|r|}
\hline Boyut & Ort & SS & $\mathbf{1}$ & $\mathbf{2}$ & $\mathbf{3}$ & $\mathbf{4}$ & $\mathbf{5}$ & $\mathbf{6}$ \\
\hline 1.Mutluluk & 3.41 & 0.75 & 1 & & & & & \\
\hline 2.Bilgiye Erișememe & 3.16 & 0.93 & -.02 & 1 & & & & \\
\hline 3.Bağlantıyı Kaybetme & 3.00 & 0.97 & $-.124^{*}$ & $.395^{* *}$ & 1 & & & \\
\hline 4.İletişime Geçememe & 3.45 & 0.90 & -.009 & $.313^{* *}$ & $.495^{* *}$ & 1 & & \\
\hline 5.Rahat Hissedememe & 2.57 & 0.95 & -.057 & $.291^{* *}$ & $.506^{* *}$ & $.348^{* *}$ & 1 & \\
\hline 6.Nomofobi & 3.07 & 0.70 & -.071 & $.625^{* *}$ & $.819^{* *}$ & $.764^{* *}$ & $.732^{* *}$ & 1 \\
\hline
\end{tabular}

$* * \mathrm{p}>0,01 * \mathrm{p}>0,05$

$\mathrm{Bu}$ bulgulardan hareketle $\mathrm{H}_{1}, \mathrm{H}_{2 \mathrm{a}}, \mathrm{H}_{2 \mathrm{c}}, \mathrm{H}_{2 \mathrm{~d}}$ hipotezleri reddedilmiştir. $\mathrm{Bu}$ gruptaki hipotezlerden sadece "Öğrencilerin nomofobi alt boyutlarından olan "Bağlantıyı Kaybetme" ile mutluluk hisleri arasında negatif yönlü bir ilişki vardır" şeklinde ifade edilen $\mathrm{H}_{2 b}$ hipotezi kabul edilmiştir.

\subsection{Farklılıklara ilişkin bulgular}

Araştırmaya katılanların demografik özellikleri ve Nomofobi durumları arasında farklılık olup olmadığını karşılaştırmak için Anova analizi uygulanmıştır. Sonuçlar aşağıdaki tabloda özetlenmiştir.

\subsubsection{Cinsiyete İliş̧kin Bulgular}

Öğrencilerin cinsiyet farklılıklarının nomofobi ve nomofobi alt boyutları arasında fark olup olmadığını kontrol etmek amacıyla tek yönlü varyans analizi (ANOVA) yapılmıştır. Tablo 6'da verilen analiz sonuçlarına göre, öğrencilerin cinsiyet değişkeni açısından nomofobinin alt boyutu olan bağlantiyl kaybetme $(\mathrm{F}=9.902, \mathrm{p}=.002)$, iletişime geçememe $(\mathrm{F}=29.802, \mathrm{p}=.000)$, ve nomofobi $(\mathrm{F}=9.771$, $\mathrm{p}=.002$ ) düzeyleri arasında anlamlı sayılabilecek ölçütte farklılık göstermektedir. Ortalamalar dikkate alındığında, kadınların bağlantıyı kaybetme (ort=3.17) ve iletişime geçememe (ort=3.77) korkuları ile nomofobi düzeyleri (ort=3.19) erkeklere (ort=2.86) $($ ort=3.29) $($ ort=2.98) göre daha yüksek olduğu söylenebilir.

Tablo 6. Cinsiyet Değişkeni Açısından Nomofobi Faktörüne İlişkin Tek Yönlü Varyans Analizi

\begin{tabular}{lllll|cc}
\hline Boyut & Cinsiyet & N & X & SS & F & P \\
\hline Bağlantıyı & Erkek & 221 & 2.86 & .98 & 9.902 & .002 \\
Kaybetme & Kadın & 174 & 3.17 & .93 & & \\
\hline İletişime & Erkek & 221 & 3.29 & .92 & 29.802 & .000 \\
Geçememe & Kadın & 174 & 3.77 & .80 & & \\
\hline \multirow{2}{*}{ Nomofobi } & Erkek & 221 & 2.98 & .70 & 9.771 & .002 \\
\cline { 2 - 5 } & Kadın & 174 & 3.19 & .67 & & \\
\hline
\end{tabular}




\subsubsection{Yaşa İlişkin Bulgular}

Öğrencilerin yaş aralıklarına göre nomofobi ve nomofobi alt boyutları arasında fark olup olmadığını kontrol etmek amacıyla tek yönlü varyans analizi (ANOVA) yapılmıştır. Tablo 7'de verilen analiz sonuçlarına göre, öğrencilerin yaş değişkenleri açısından nomofobinin alt boyutu olan iletişime geçememe düzeyleri arasında anlamlı sayılabilecek ölçütte farklılık göstermektedir $(\mathrm{F}=7.251, \mathrm{p}=.001)$. Bu farklılığın hangi sıklık grupları arasında olduğunu saptamak için Post-Hoc testi kullanılmıştır. Buna göre, 17-23 yaş aralığındaki öğrencilerin (ort=3.57) nomofobi düzeylerinin, 23-28 yaş aralığında (ort=3.13) bulunan öğrenci gruplarına göre yüksek olduğunu gösteren anlamlı bir farklılık tespit edilmiştir. Bu bulgulara göre genç gruplarda nomofobi düzeyinin daha yüksek olduğu söylenebilir. aynı şekilde genç grubun teknolojiyle daha çok ilgilenmeleri ve bu dönemde büyümeleri de böyle bir bulgunun ortaya çıkmasında önemli bir etken olabilir.

Tablo 7. Yaş Değişkeni Açısından Nomofobi Faktörüne İlişkin Tek Yönlü Varyans Analizi

\begin{tabular}{lllll:lll}
\hline Boyut & Yaş Grubu & $\mathrm{N}$ & $\mathrm{X}$ & $\mathrm{SS}$ & $\mathrm{F}$ & $\mathrm{P}$ & Anlamlı Fark \\
\hline \multirow{2}{*}{$\begin{array}{l}\text { İletişime } \\
\text { Geçememe }\end{array}$} & $17-23$ & 331 & 3.57 & .89 & 7.251 & .001 & $(17-23$ Yaş)- \\
\cline { 2 - 7 } & $23-28$ & 59 & 3.13 & .87 & & & $(23-28$ yaş) \\
\cline { 2 - 7 } & 28 ve üzeri & 5 & 2.97 & .72 & & & \\
\hline
\end{tabular}

\subsubsection{Sınıf Değişsenine Göre Bulgular}

Öğrencilerin sınıflarına göre nomofobi ve nomofobi alt boyutları arasında fark olup olmadığını kontrol etmek amacıyla tek yönlü varyans analizi (ANOVA) yapılmıştır. Yapılan analize göre öğrencilerin bulundukları sınıf ile nomofobi ve nomofobi alt boyutları üzerinde ortalamalar arasında $\mathrm{p}<0,05$ önem düzeyinde anlamlı bir farkl1lık tespit edilememiştir.

\subsubsection{Akılı Telefon Kullanım Süresine Göre Bulgular}

Öğrencilerin akıllı telefon kullanım süreleri ile nomofobi ve nomofobi alt boyutları arasında fark olup olmadığını kontrol etmek amacıyla tek yönlü varyans analizi (ANOVA) yapılmıştır. Tablo 8'de verilen analiz sonuçlarına göre, öğrencilerin akıllı telefon kullanım süreleri değiş̧eni açısından nomofobi $(\mathrm{F}=4.374, \mathrm{p}=.005)$, nomofobinin alt boyutu olan iletişime geçememe $(\mathrm{F}=4.456, \mathrm{p}=.004)$ ve bağlantiyl kaybetme $(\mathrm{F}=3.301, \mathrm{p}=.020)$ düzeyleri arasında anlamlı sayılabilecek ölçütte farklılık göstermektedir. $\mathrm{Bu}$ farklılıkların hangi sıklık grupları arasında olduğunu saptamak için Post-Hoc testi kullanılmıştır. Buna göre, 1 yıldan az süredir akıllı telefon kullanan öğrencilerin nomofobi (ort=2.61), bağlantıyı kaybetme (ort=2.40) ve iletişime geçememe (ort=2.90) düzeylerinin, telefonunu 3-4 yıl kullanan öğrenci gruplarının 
nomofobi (ort=3.22), bağlantıyı kaybetme (ort=3.17) ve iletişime geçememe (ort=3.71) düzeylerine göre daha düşük olduğunu gösteren anlamlı bir farklılık tespit edilmiştir. bu bulgu aslında beklenen bir bulgudur çünkü telefonu kullanma süresi arttıkça bu cihaza bağlanma olasılığı daha da artabilmekte ve hayatın içerisinde daha fazla yer edinebilmektedir.

Tablo 8. Akıllı Telefon Kullanım Süresi Değişkeni Açısından Nomofobi Faktörüne İlişkin Tek Yönlü Varyans Analizi

\begin{tabular}{|c|c|c|c|c|c|c|c|}
\hline Boyut & Süre & $\mathbf{N}$ & $\mathbf{X}$ & SS & $\mathbf{F}$ & $\mathbf{P}$ & Anlamlı Fark \\
\hline \multirow{4}{*}{$\begin{array}{l}\text { Bağlantıyı } \\
\text { Kaybetme }\end{array}$} & 1 Yildan az & 12 & 2.40 & 1.04 & \multirow[t]{4}{*}{3.301} & \multirow[t]{4}{*}{.020} & \multirow{4}{*}{$\begin{array}{l}\text { (1 y1ldan az)- } \\
(3-4 \text { y1l) }\end{array}$} \\
\hline & $1-2$ y1l & 69 & 2.85 & .92 & & & \\
\hline & $3-4$ y1l & 115 & 3.17 & .97 & & & \\
\hline & 4 yıl ve üzeri & 199 & 2.98 & .97 & & & \\
\hline \multirow{4}{*}{$\begin{array}{l}\text { İletişime } \\
\text { Geçememe }\end{array}$} & 1 Yildan az & 12 & 2.90 & .90 & \multirow[t]{4}{*}{4.456} & \multirow[t]{4}{*}{.004} & \multirow{4}{*}{$\begin{array}{l}\text { (1 y1ldan az)- } \\
(3-4 \text { y1l) }\end{array}$} \\
\hline & $1-2$ y1l & 69 & 3.39 & .96 & & & \\
\hline & $3-4$ y1l & 115 & 3.71 & .81 & & & \\
\hline & 4 yil ve üzeri & 199 & 3.45 & .91 & & & \\
\hline \multirow{4}{*}{ Nomofobi } & 1 Yildan az & 12 & 2.61 & .50 & \multirow[t]{4}{*}{4.374} & \multirow[t]{4}{*}{.005} & \multirow{4}{*}{$\begin{array}{l}\text { (1 y1ldan az)- } \\
(3-4 \text { y1l) }\end{array}$} \\
\hline & $1-2$ y1l & 69 & 2.96 & .64 & & & \\
\hline & 3-4 yil & 115 & 3.22 & .68 & & & \\
\hline & 4 yıl ve üzeri & 199 & 3.05 & .71 & & & \\
\hline
\end{tabular}

Bu bulgulara göre akı1lı telefonu 3 yıldan daha fazla kullanan öğrenci gruplarında nomofobi, bağlantıyı kaybetme ve iletişime geçememe düzeyleri, akıllı telefonu yeni kullanmaya başlayan öğrenci gruplarına göre daha yüksektir. Buradan akıllı telefonu kullanım süresi arttıkça, öğrenciler telefona daha bağımlı hale geldiği söylenebilir.

\subsubsection{Günlük Telefonu Kontrol Etme Sıklığına İlişkin Bulgular}

Öğrencilerin günlük akıllı telefon kontrol etme sıkılı̆ğ ile nomofobi ve nomofobi alt boyutları arasında fark olup olmadığını kontrol etmek amacıyla tek yönlü varyans analizi (ANOVA) yapılmıştır. Tablo 9'da verilen analiz sonuçlarına göre, öğrencilerin günlük akıllı telefon kontrol etme sıkılığı değişkeni açısından nomofobinin alt boyutu olan bilgiye erişememe $(\mathrm{F}=9.206, \mathrm{p}=.000)$, bağlantıyı kaybetme $(\mathrm{F}=16.368, \mathrm{p}=.000)$, iletişime geçememe $(\mathrm{F}=7.502, \mathrm{p}=.000)$, rahat hissedememe $(\mathrm{F}=3.598, \mathrm{p}=.014)$ ve nomofobi $(\mathrm{F}=15.110, \mathrm{p}=.000)$ düzeyleri arasında anlamlı sayılabilecek ölçütte farklılık göstermektedir.

$\mathrm{Bu}$ farklılıkların hangi sıklık grupları arasında olduğunu saptamak için PostHoc testi kullanılmıştır. Buna göre, akıllı telefonunu günde 1-16 kez (ort=2.90) kontrol eden öğrencilerin nomofobi alt boyutu olan bilgiye erişememe düzeylerinin, 
akıllı telefonu günde $33-48 \mathrm{kez}$ (ort=3.42) ve 48 'den daha fazla (ort=3.42) kontrol eden öğrenci gruplarına göre düşük olduğunu gösteren anlamlı bir farklılık tespit edilmiştir. Akıllı telefonunu günde 1-16 kez (ort=2.64) kontrol eden öğrencilerin nomofobi alt boyutu olan bağlantıyı kaybetme düzeylerinin, akıllı telefonu günde 33$48 \mathrm{kez}$ (ort=3.19) ve 48'den daha fazla (ort=3.43) kontrol eden öğrenci gruplarına göre düşük olduğunu gösteren anlamlı bir farklılık tespit edilmiştir. Akıllı telefonunu günde 1-16 kez (ort=3.20) kontrol eden öğrencilerin nomofobi alt boyutu olan iletişime geçememe düzeylerinin, akıllı telefonu günde 33-48 kez (ort=3.68) ve 48 'den daha fazla (ort=3.72) kontrol eden öğrenci gruplarına göre düşük olduğunu gösteren anlamlı bir farklılık tespit edilmiştir. Akıllı telefonunu 1-16 kez (ort=2.38) kontrol eden öğrencilerin nomofobi alt boyutu olan rahat hissedememe düzeylerinin, akı1lı telefonu günde 48 den daha fazla (ort=2.80) kontrol eden öğrenci gruplarına göre daha düşük olduğunu gösteren anlamlı bir farklılık tespit edilmiştir. Akıllı telefonunu günde 1-16 kez (ort=2.79) kontrol eden öğrencilerin nomofobi düzeylerinin, akıllı telefonu günde $16-32 \mathrm{kez}$ (ort=2.97) ve 48 'den daha fazla (ort=3.36) kontrol eden öğrenci gruplarına göre düşük olduğunu gösteren anlamlı bir farklılık tespit edilmiştir.

Tablo 9. Günlük Telefonu Kontrol Etme Sıklığı Değişkeni Açısından Nomofobi Faktörüne İlişkin Tek Yönlü Varyans Analizi

\begin{tabular}{|c|c|c|c|c|c|c|c|}
\hline Boyut & Sıklık & $\mathbf{N}$ & $\mathbf{X}$ & SS & $\mathbf{F}$ & $\mathbf{P}$ & Anlamlı Fark \\
\hline \multirow{4}{*}{$\begin{array}{l}\text { Bilgiye } \\
\text { Erişememe }\end{array}$} & $1-16$ & 108 & 2.90 & .96 & \multirow[t]{4}{*}{9.206} & \multirow[t]{4}{*}{.000} & \multirow{4}{*}{$\begin{array}{l}(1-16 \mathrm{kez})-(33- \\
48 \mathrm{kez})(48 \mathrm{kez} \\
\text { ve üzeri) }\end{array}$} \\
\hline & $16-32$ & 110 & 3.00 & .90 & & & \\
\hline & $33-48$ & 68 & 3.42 & .87 & & & \\
\hline & 48 ve üzeri & 109 & 3.42 & .85 & & & \\
\hline \multirow{4}{*}{$\begin{array}{l}\text { Bağlantıyı } \\
\text { Kaybetme }\end{array}$} & $1-16$ & 108 & 2.64 & .90 & \multirow[t]{4}{*}{16.368} & \multirow[t]{4}{*}{.000} & \multirow{4}{*}{$\begin{array}{l}(1-16 \mathrm{kez})-(33- \\
48 \mathrm{kez})(48 \mathrm{kez} \\
\text { ve üzeri) }\end{array}$} \\
\hline & $16-32$ & 110 & 2.79 & .95 & & & \\
\hline & $33-48$ & 68 & 3.19 & .93 & & & \\
\hline & 48 ve üzeri & 109 & 3.43 & .89 & & & \\
\hline \multirow{4}{*}{$\begin{array}{l}\text { İletişime } \\
\text { Geçememe }\end{array}$} & $1-16$ & 108 & 3.20 & .90 & \multirow[t]{4}{*}{7,502} & \multirow[t]{4}{*}{,000 } & \multirow{4}{*}{$\begin{array}{l}(1-16 \mathrm{kez})-(33- \\
48 \mathrm{kez})(48 \mathrm{kez} \\
\text { ve üzeri) }\end{array}$} \\
\hline & $16-32$ & 110 & 3.47 & .94 & & & \\
\hline & $33-48$ & 68 & 3.68 & .77 & & & \\
\hline & 48 ve üzeri & 109 & 3.72 & .86 & & & \\
\hline \multirow{4}{*}{$\begin{array}{l}\text { Rahat } \\
\text { Hissedememe }\end{array}$} & $1-16$ & 108 & 2.38 & .91 & \multirow[t]{4}{*}{3,598} & \multirow[t]{4}{*}{,014 } & \multirow{4}{*}{$\begin{array}{l}(1-16 \text { kez)-(48 } \\
\text { kez ve üzeri) }\end{array}$} \\
\hline & $16-32$ & 110 & 2.53 & .94 & & & \\
\hline & $33-48$ & 68 & 2.54 & .94 & & & \\
\hline & 48 ve üzeri & 109 & 2.80 & .99 & & & \\
\hline \multirow{4}{*}{ Nomofobi } & $1-16$ & 108 & 2.79 & .66 & \multirow[t]{4}{*}{15.110} & \multirow[t]{4}{*}{.000} & \multirow{4}{*}{$\begin{array}{l}(1-16 \mathrm{kez})-(33- \\
48 \mathrm{kez})(48 \mathrm{kez} \\
\text { ve üzeri) }\end{array}$} \\
\hline & $16-32$ & 110 & 2.97 & .68 & & & \\
\hline & $33-48$ & 68 & 3.22 & .65 & & & \\
\hline & 48 ve üzeri & 109 & 3.36 & .65 & & & \\
\hline
\end{tabular}

\subsection{6. Şarj Aleti Bulundurma Durumuna İlişkin Bulgular}

Öğrencilerin yanında şarj aleti bulundurma durumuna ilişkin nomofobi ve nomofobi alt boyutları arasında fark olup olmadığını kontrol etmek amaciyla tek 
yönlü varyans analizi (ANOVA) yapılmıştır. Tablo 10'da verilen analiz sonuçlarına göre, öğrencilerin yanında şarj aleti bulundurma durumu değişkeni açısından nomofobinin alt boyutu olan bağlantıyı kaybetme $(\mathrm{F}=13.982, \mathrm{p}=.000)$ ve nomofobi $(\mathrm{F}=6.225, \quad \mathrm{p}=.013)$ düzeyleri arasında anlamlı sayılabilecek ölçütte farklılık göstermektedir. Yanında şarj cihazı bulunduran (ort=3.24) öğrencilerin bağlantıyı kaybetme korkuları, bulundurmayan (ort=2.86) öğrencilere göre daha fazla olduğu söylenebilir.

Tablo 10. Şarj Aleti Bulundurma Değişkeni Açısından Nomofobi Faktörüne Ílişkin Tek Yönlü Varyans Analizi

\begin{tabular}{lllll|cr}
\hline Boyut & Şarj Aleti & N & X & SS & F & P \\
\hline \multirow{2}{*}{ Bağlantıyı Kaybetme } & Evet & 142 & 3.24 & .98 & 13.982 & .000 \\
\cline { 2 - 6 } & Hayır & 253 & 2.86 & .94 & & \\
\hline \multirow{2}{*}{ Nomofobi } & Evet & 142 & 3.19 & .75 & 6.225 & .013 \\
\cline { 2 - 5 } & Hayır & 253 & 3.00 & .66 & & \\
\hline
\end{tabular}

\subsubsection{Uyanır Uyanmaz Akıllı Telefonu Kontrol Etme Durumuna İlişkin}

\section{Bulgular}

Öğrencilerin uyanır uyanmaz akıllı telefon kontrol etme durumu ile nomofobi ve nomofobi alt boyutları arasında fark olup olmadığını kontrol etmek amacıyla tek yönlü varyans analizi (ANOVA) yapılmıştır. Tablo 11'de verilen analiz sonuçlarına göre, öğrencilerin uyanır uyanmaz akıllı telefon kontrol etme durumu açısından nomofobinin alt boyutu olan bilgiye erişememe $(\mathrm{F}=10.534, \mathrm{p}=.001)$, bağlantıyı kaybetme $(\mathrm{F}=50.879, \mathrm{p}=.000)$, iletişime geçememe $(\mathrm{F}=12.848, \mathrm{p}=.000)$, rahat hissedememe $(\mathrm{F}=17.827, \mathrm{p}=.000)$ ve nomofobi $(\mathrm{F}=39.331, \mathrm{p}=.000)$ düzeyleri arasında anlamlı sayılabilecek ölçütte farklılık göstermektedir. Ortalamalar dikkate alındı̆̆ında, uyanınca telefonunu kontrol eden öğrencilerin bilgiye erişememe (ort=3.25), bağlantıyı kaybetme (ort=3.19), iletişime geçememe (ort=3.59), rahat hissedememe (ort=2.68) ve nomofobi (ort=3.20) düzeyleri, uyanınca telefonunu kontrol etmeyenlere göre daha yüksek olduğu söylenebilir.

Tablo 11. Uyanır Uyanmaz Akıllı Telefonu Kontrol Etme Değişkeni Açısından Nomofobi Faktörüne İliş̧in Tek Yönlü Varyans Analizi

\begin{tabular}{|c|c|c|c|c|c|c|}
\hline Boyut & Durum & $\mathbf{N}$ & $\mathbf{X}$ & SS & $\mathbf{F}$ & $\mathbf{P}$ \\
\hline \multirow{2}{*}{ Bilgiye Erişememe } & Evet & 294 & 3.25 & .91 & \multirow[t]{2}{*}{10.534} & \multirow[t]{2}{*}{.001} \\
\hline & Hayır & 101 & 2.91 & .94 & & \\
\hline \multirow{2}{*}{ Bağlantıyı Kaybetme } & Evet & 294 & 3.19 & .92 & \multirow[t]{2}{*}{50.879} & \multirow[t]{2}{*}{.000} \\
\hline & Hayır & 101 & 2.44 & .90 & & \\
\hline \multirow{2}{*}{ İletişime Geçememe } & Evet & 294 & 3.59 & .86 & \multirow[t]{2}{*}{12.848} & \multirow[t]{2}{*}{.000} \\
\hline & Hayır & 101 & 3.23 & .96 & & \\
\hline \multirow{2}{*}{ Rahat Hissedememe } & Evet & 294 & 2.68 & .94 & \multirow[t]{2}{*}{17.827} & \multirow[t]{2}{*}{.000} \\
\hline & Hayır & 101 & 2.23 & .92 & & \\
\hline \multirow{2}{*}{ Nomofobi } & Evet & 294 & 3.20 & .67 & \multirow[t]{2}{*}{39.331} & \multirow[t]{2}{*}{.000} \\
\hline & Hayır & 101 & 2.71 & .65 & & \\
\hline
\end{tabular}




\subsubsection{Yatmadan Önce Akıllı Telefon İle Zaman Geçirme Durumuna İlişkin Bulgular}

Öğrencilerin yatmadan önce akıllı telefon ile zaman geçirme durumu ile nomofobi ve nomofobi alt boyutları arasında fark olup olmadığını kontrol etmek amacıyla tek yönlü varyans analizi (ANOVA) yapılmıştır. Tablo 12'de verilen analiz sonuçlarına göre, öğrencilerin yatmadan önce akıllı telefon ile zaman geçirme durumu açısından nomofobinin alt boyutu olan bilgiye erişememe $(\mathrm{F}=4.469, \mathrm{p}=.035)$, bağlantıyı kaybetme $(\mathrm{F}=6.339, \mathrm{p}=.12)$, iletişime geçememe $(\mathrm{F}=6.298, \mathrm{p}=.012)$, ve nomofobi $(\mathrm{F}=8.073, \mathrm{p}=.005)$ düzeyleri arasında anlamlı sayılabilecek ölçütte farklılık göstermektedir. Ortalamalar dikkate alındığında, yatmadan önce telefonu ile zaman geçiren öğrencilerin bilgiye erişememe (ort=3.19), bağlantıyı kaybetme (ort=3.04), iletişime geçememe (ort=3.54) ve nomofobi (ort=2.59) düzeyleri, yatmadan önce telefonunu ile zaman geçirmeyen öğrencilere göre daha yüksek olduğu söylenebilir.

Tablo 12. Yatmadan Önce Akıllı Telefon İle Zaman Geçirme Değişkeni Açısından Nomofobi Faktörüne İliş̧in Tek Yönlü Varyans Analizi

\begin{tabular}{|c|c|c|c|c|c|c|}
\hline Boyut & Durum & $\mathbf{N}$ & $\mathbf{X}$ & SS & $\mathbf{F}$ & $\mathbf{P}$ \\
\hline \multirow{2}{*}{ Bilgiye Erişememe } & Evet & 355 & 3.19 & .92 & \multirow[t]{2}{*}{4.469} & \multirow[t]{2}{*}{.035} \\
\hline & Hayır & 40 & 2.87 & .96 & & \\
\hline \multirow{2}{*}{ Bağlantıyı Kaybetme } & Evet & 355 & 3.04 & .96 & \multirow[t]{2}{*}{6.399} & \multirow[t]{2}{*}{.012} \\
\hline & Hayır & 40 & 2,63 & .97 & & \\
\hline \multirow{2}{*}{ İletişime Geçememe } & Evet & 355 & 3.54 & .89 & \multirow[t]{2}{*}{6.298} & \multirow[t]{2}{*}{.012} \\
\hline & Hayır & 40 & 3.16 & .91 & & \\
\hline \multirow{2}{*}{ Nomofobi } & Evet & 355 & 2.59 & .95 & \multirow[t]{2}{*}{8.073} & \multirow[t]{2}{*}{.005} \\
\hline & Hayır & 40 & 2.40 & .97 & & \\
\hline
\end{tabular}

\subsubsection{Akılı Telefonu Gece Kapatma Durumuna İlişkin Bulgular}

Öğrencilerin akıllı telefonlarını gece kapatma durumu ile nomofobi ve nomofobi alt boyutları arasında fark olup olmadığını kontrol etmek amacıyla tek yönlü varyans analizi (ANOVA) yapılmıştır. Tablo 13'de verilen analiz sonuçlarına göre, öğrencilerin gece telefonu kapatma durumu açısından nomofobinin alt boyutu olan bağlantıyı kaybetme $(\mathrm{F}=6.895, \mathrm{p}=.009)$ ve nomofobi $(\mathrm{F}=3.916, \mathrm{p}=.049)$ düzeyleri arasında anlamlı sayılabilecek ölçütte farklılık göstermektedir. Ortalamalar dikkate alındığında, gece telefonunu kapatmayan öğrencilerin bağlantıyı kaybetme (ort=3.05) ve nomofobi (ort=3.10) düzeyleri, gece telefonunu kapatan öğrencilere göre daha yüksek olduğu söylenebilir. 
Tablo 13. Akıllı Telefonu Gece Kapatma Değişkeni Açısından Nomofobi Faktörüne İlişsin Tek Yönlü Varyans Analizi

\begin{tabular}{lcccc|cc}
\hline \multirow{2}{*}{ Boyut } & Durum & N & X & SS & F & P \\
\hline \multirow{2}{*}{ Bağlantıyı Kaybetme } & Evet & 69 & 2.72 & 1.07 & \multirow{2}{*}{6.895} & .009 \\
\cline { 2 - 7 } & Hayır & 326 & 3.05 & .94 & & \\
\hline \multirow{2}{*}{ Nomofobi } & Evet & 69 & 2.92 & .72 & \multirow{2}{*}{3.916} & .049 \\
\cline { 2 - 7 } & Hayır & 326 & 3.10 & .69 & & \\
\hline
\end{tabular}

\section{SONUÇ}

$\mathrm{Bu}$ çalışma nomofobi ile mutluluk arasındaki ilişkini belirlenmesine yöneliktir. Ardahan üniversitesinde okuyan öğrenciler üzerinde gerçekleştirilen bu çalışmanın sonuçları şu şekildedir: Üniversite öğrencilerinin nomofobi düzeyleri ile öznel iyi olma (mutluluk) seviyeleri arasındaki ilişki incelenmesine yönelik yapılan korelasyon analizi neticesinde nomofobinin alt boyutlarından olan bağlantıyı kaybetme korkusu ile mutluluk arasında ters yönlü ve anlamlı $(\mathrm{p}>0,05)$ bir ilişki bulunmuştur. Bağlantıyı kaybetme boyutunda en çok puanı alan ifadelere bakıldığında, öğrencilerde telefona bakmak için güçlü bir istek olduğu ve öğrencilerin sürekli sinyal olup olmadığı kontrol ettikleri görülmektedir. Bu durumda öğrencilerin bağlantıyı kaybetmekten korktuklarını ve bu korkunun mutluluk seviyelerini olumsuz yönde etkilediği söylenebilir. Bu bulguları destekleyen bazı çalışmalar vardır. Örneğin; Tavolacci $v d$.'nin (2015) 760 öğrenci üzerinde yaptıkları çalışmada problemli ve aşırı telefon kullanımının mutluluk seviyesini azalttığını tespit etmişlerdir. Yine başka bir çalışmada 279 üniversite öğrencisinin akıllı telefon bağımlılığı ile mutluluk seviyeleri arasındaki ilişki incelenmiş, bu iki değişken arasında ters yönlü ve anlamlı ilişki tespit edilmiştir (Süler, 2016).

Ortalamalara ilişkin yapılan analizden elde edilen bulgulara göre, öğrencilerin nomofobi düzeyleri orta (ort=3.07), mutluluk seviyeleri ise yüksek (ort=3.41) olarak belirlenmiştir. Nomofobinin alt boyutları incelendiğinde, öğrencilerin iletişime geçememe ve bilgiye erişememe korkularının diğerlerine göre daha fazla olduğunu söylenebilir. Bu durum Yıldırım vd. (2015) üniversite öğrencileri üzerine yaptığı ve Gezgin vd. (2017) öğretmen adaylarına yaptığı çalışma sonuçlarını doğrular niteliktedir.

Çalışmada öğrencilerin cinsiyetleri ile nomofobi ve nomofobi alt boyutları düzeyleri açısından anlamlı farklılık tespit edilmiştir. Bulgular ışığında kadınların iletişime geçememe, bağlantıyı kaybetme ve nomofobi düzeyleri, erkeklere göre daha fazladır. Literatürde Yıldırım $v d$. (2015), Lee $v d$. (2014) ve Gezgin $v d$. (2017) yaptıkları çalışmalar, bu bulguları doğrular niteliktedir. Bunların dışında İngiltere'de 
1000 kişi üzerinde yapılan (SecurEnvoy, 2012), 202 kamu çalışanı ve 265 üniversite öğrencisine gerçekleştirilen araştırmada da benzer sonuçlar çıkmıştır (Erdem $v d$., 2017).

Öğrencilerin yaşları ile nomofobi alt boyutu olan iletişime geçememe düzeyleri arasında anlamlı farklılık tespit edilmiştir. Bulgulara göre 17-23 yaş aralığındaki öğrenciler 23-28 yaş aralığındaki öğrencilere göre daha fazla iletişime geçememe kaygısı yaşamaktadırlar. Yani yaş ilerledikçe bu korku azalmaktadır. Yıldıım vd. (2015) ile SecurEnvoy (2012) tarafindan yapılan çalışmalarda da benzer sonuçlara ulaşılmıştır. Bunların dışında Aktaş ve Yılmaz (2017) tarafından yapılan çalışmada 18-21 yaş aralı̆̆ındaki katılımcıların 22-25 yaş aralığındaki katılımcılara göre akıllı telefon bağımlılı̆̆ın daha fazla olduğu anlamlı olarak tespit edilmiş̧ir. Diğer taraftan, yaşa iliş̧kin değişkenlerin aksine öğrencilerin sınıf düzeyleri ile nomofobi ve nomofobi alt boyutları arasında anlamlı bir farklılık tespit edilememiştir.

Öğrencilerin akıllı telefon kullanım süresi ile nomofobi ve nomofobi alt boyutları arasında anlamlı farklılık tespit edilmiştir. Bulgulara göre 1 yıldan az süredir akıllı telefon kullanan öğrencilerin bağlantıyı kaybetme, iletişime geçememe ve nomofobi düzeyleri, akıllı telefonunu 3-4 yıldır kullanan öğrenci gruplarına göre daha düşüktür. Yani akıllı telefon kullanım süresi arttıkça öğrencilerin telefondan uzak kalma korkusu da artmaktadır ve telefon kişide bağımlılık yaratmaktadır. Bizim çalışmamıza paralel olarak Nikhita (2015) $v d$.'nin yaptığı çalışmada 3 yıldan az süre telefon kullananların, 3 yıldan fazla kullananlara göre telefon bağımlılı̆̆ın daha az olduğunu tespit etmiştir. Bunun dışında 495 öğrenciye yapılan başka bir çalışmada akıllı telefon kullanımı daha eskilere dayanan öğrencilerde nomofobi düzeyinin daha yüksek olduğu rapor edilmiştir (Hoşgör $v d$., 2017).

Öğrencilerin günlük akıllı telefon kontrol etme sıkılığı ile nomofobi ve nomofobi alt boyutları arasında anlamlı farklılık tespit edilmiştir. Yani günlük telefonunu kontrol etme sıklığı 33 den fazla olan öğrencilerin nomofobi düzeyleri, 1$16 \mathrm{kez}$ kontrol eden öğrencilere göre daha fazladır. Bu sonuçlar ilgili literatürleri destekler niteliktedir. Örneğin 683 öğrenci üzerinde yapılan bir çalışmada akıllı telefonunu daha fazla kontrol eden öğrencilerin nomofobi düzeylerinin, daha az kontrol eden öğrencilere göre daha fazla olduğu tespit edilmiştir (Akılll, Gezgin, 2016). Başka bir çalışmada araştırmaya katılan yaklaşık 15000 kişinin neredeyse yarısının bir saatte birkaç kez telefonunu kontrol ettiği tespit edilmiştir (Newport, 2015).

Öğrencilerin yanında şarj aleti bulundurma durumu ile nomofobi ve bağlantıyı kaybetme korkusu arasında anlamlı farklılık bulunmuştur. Buna göre, yanında şarj aleti bulunduran öğrencilerin nomofobi ve bağlantıy1 kaybetme düzeyi bulundurmayan öğrencilere göre daha yüksektir. Nomofobik birey telefonunun şarjının bitmesi konusunda kaygı taşımaktadır. Bundan dolayı birey şart aletini 
yanında taşıyıp bataryasının bitmesi durumunda telefonunu şarj edecektir. Literatür incelendiğinde araştırmanın sonuçlarına benzer çalışmalar yer almaktadır (Akıllı, Gezgin, 2016; Hoşgör $v d$., 2017).

Çalışmada, öğrencilerin uyanır uyanmaz akıllı telefonu kontrol etme durumu ile nomofobi ve nomofobi alt boyutları arasında anlamlı farklılık bulunmuştur. Uyanınca telefonu kontrol eden öğrencilerin bilgiye erişememe, bağlantıyı kaybetme, iletişime geçememe, rahat hissedememe ve nomofobi düzeyleri; telefonunu kontrol etmeyen öğrencilere göre daha yüksektir. Bunun yanında, öğrencilerin gece telefonu kapatma durumu ile de nomofobi ve nomofobi alt boyutları arasinda anlamlı farkl11ık bulunmuştur. Buna göre yatarken telefonunu kapatan öğrencilerin bilgiye erişememe, bağlantıyı kaybetme, iletişime geçememe ve nomofobi düzeyleri; kapatmayanlara göre daha yüksektir. Sik sık telefonu kontrol etmek, gece yatağa telefonla girmek ve telefondan kopamamak telefon bağımlılığı ve nomofobinin özellikleri arasında yer almaktadır (Akıllı, Gezgin, 2016: 61). Bu bulguların ışığında, Akıllı ve Gezgin (2016) ile Hoşgör $v d$. (2017)'nin yaptıkları çalışmalar ile bu sonuçlar birbirini desteklemektedirler.

Son olarak öğrencilerin telefonu gece kapatma durumu ile bağlantıyı kaybetme ve nomofobi düzeyler arasında anlamlı farklılık vardır. Gece telefonu kapatan öğrencilerin bağlantıyı kaybetme ve nomofobi düzeyleri, kapatmayanlara göre daha yüksektir. Öğrenciler gece telefonlarını kapatmayarak 24 saat bağlantıda kalmak istemekte, gelen aramaları ve mesajları kaçırmak istememektedirler. Üniversite öğrencileri üzerinde yapılan bir çalışmada öğrencilerin tamamının telefonunu 24 saat açık tuttuğu belirtilmiştir (Özaşçılar, 2012). Bu durum öğrencilerde uykusuzluk sorunlarının başlamasına, ertesi gün odaklanma ve öğrenme güçlüğü çekmelerine sebep olabilir.

21 yüzyılın hastalığı olarak tanımlanan nomofobi hakkında farkındalık oluşturmak için medya ve internette birçok haber yapılmakta ve insanların bilinç düzeyi artırılmaktadır. Ülkemizde önemli bir kuruluş olan Yeşilay, teknoloji bağımlılı̆̆ını da mücadele alanına dahil etmiştir. Bununla birlikte, bazı hastaneler bu bağımlılı̆̆ tedavi etme konusunda daha öncü hale gelmekte ve tedavisi ile ilgili terapiler uygulamaktadır. Toplumsal düzeyde bu bağımlılığın önüne geçilebilmesi adına başta aile üyelerinin, eğitimcilerin ve medyanın bağımlılık oluşturabilecek etkenler üzerindeki tetikleyici unsurların ortadan kaldırılması ya da azaltılması yönünde çalışmalar yapılmalıdır. Bu önleyici tedbirler çeşitli eğitici araçlar ve programlar aracılığıyla uygulanabilir. Kişilerin ise kendi bilinç düzeylerini oluşturmaları ve farkındalık sahibi olmaları adına bu konuya gereken önemi vermeleri gerekmektedir. Bağımlılık sınırına yaklaşan veya bağımlı olan bireylerin tedaviden kaçmamaları mümkün olan en kısa zamanda bağımlılık düzeyleri oluşmadan veya artmadan harekete geçmeleri gerekmektedir. 
Üniversite Öğrencilerinin Nomofobi Düzeyi İle Öznel İyi Olma ...| GÜLLÜCE, KAYGIN, BÖREKÇİ

Çalı̧̧mamızın öğrencilerin nomofobi düzeyleri ile öznel iyi hissetme (mutluluk) durumları arasında daha önce yapılan ender çalışmalardan biri olmasından dolayı özgün bir değere sahip olduğu düşünülmektedir. Çalışma sonucunda elde edilen bulgulara göre sonuçların tam anlamıyla katkı sağlaması ve genelleme yapılabilmesi adına örgütsel bağlamda benzer çalışmaların yapılmasının faydalı olacağı düşünülmektedir. Ayrıca yapılacak olan çalışmalarda bölüm/meslek-görev bazında bir değerlendirme yapılması da araştırılması gereken diğer faktörler olarak değerlendirilmektedir.

\section{KAYNAKÇA}

Abraham, N., J., Mathias, S. Williams (2014), "A Study to Assess The Knowledge and Effect of Nomophobia Among Students of Selected Degree Colleges in Mysore", Asian Journal of Nursing Education and Research, 4(4), 421-428.

Akıllı, G.K., D.M. Gezgin (2016), "Üniversite Öğrencilerinin Nomofobi Düzeyleri ile Farklı Davranış Örüntülerinin Arasındaki İlişkilerin İncelenmesi”, Mehmet Akif Ersoy Üniversitesi Eğitim Fakültesi Dergisi, 40, 51-69.

Aktaş, H., N. Yılmaz (2017), "Üniversite Gençlerinin Yalnızlık ve Utangaçlık Unsurları Açısından Akıllı Telefon Bağımlılı̆̆ı”, International Journal of Social Sciences and Education Research, 3(1), 85-100.

Akyüz, H., F. Yaşartürk, İ. Karataş, M. Türkmen, E. Zorba (2018), "Rekreasyon Bölümünde Öğrenim Gören Öğrencilerin Serbest Zaman Motivasyonlarının Mutluluk Düzeyleri Üzerine Etkisi”, Journal of Human Sciences, 15(2), 1086-1096.

Argumosa-Villar, L., J. Boada-Grau, A. Vigil-Colet (2017), "Exploratory Investigation of Theoretical Predictors of Nomophobia Using the Mobile Phone Involvement Questionnaire (MPIQ)", Journal of Adolescence, 56, 127-135.

Arpaci, I. (2017), "Culture and Nomophobia: The Role of Vertical versus Horizontal Collectivism in Predicting Nomophobia", Information Development, 1-11.

Augner, C., G.W. Hacker (2012), "Associations Between Problematic Mobile Phone Use and Psychological Parameters in Young Adults", International Journal of Public Health, 57(2), 437-441.

Beranuy, M., U. Oberst, X. Carbonell, A. Chamarro (2009), "Problematic Internet and Mobile Phone Use and Clinical Symptoms in College Students: The Role of Emotional Intelligence", Computers in Human Behavior, 25(5), 1182-1187.

Bragazzi, N.L., G. Del Puente (2014), "A Proposal For Including Nomophobia in the New Dsm-V", Psychology Research and Behavior Management, 7, 155-160.

Clayton, R.B., G. Leshner, A. Almond (2015), "The Extended Iself: The Impact of Iphone Separation on Cognition, Emotion, and Physiology", Journal of Computer-Mediate Communication, 20(2), 1-17. 
Demir, R., M. Murat (2017), "Öğretmen Adaylarının Mutluluk, İyimserlik, Yaşam Anlamı ve Yaşam Doyumlarının İncelenmesi”, OPUS-Uluslararası Toplum Araştırmaları Dergisi, 7(13), 347-378

Dempsey, A.G., M.L. Sulkowski, R. Nichols, E.A. Storch (2009), "Differences Between Peer Victimization in Cyber and Physical Settings and Associated Psychosocial Adjustment in Early Adolescence”, Psychology in the Schools, 46(10), 962-972.

Diener, E., M. Diener (1995), "Cross-Cultural Correlates of Life Satisfaction and Self-Esteem. In Culture and Well-Being”, Journal of Personality and Social Psychology, 68(4), 653-663.

Diener, E. (2000), "Subjective Well-Being: The Science of Happiness and a Proposal for a National Index", American Psychologist, 55(1), 34-43.

Doğan, T., N.A. Çötok (2011), "Oxford Mutluluk Ölçeği Kısa Formunun Türkçe Uyarlaması: Geçerlik ve Güvenirlik Çalışması”, Türk Psikolojik Danışma ve Rehberlik Dergisi, 4(36), 165-172.

Doğan, T. (2013), Beş Faktör Kişilik Özellikleri ve Öznel İyi Oluş. Doğuş Üniversitesi Dergisi, 14(1), 56-64.

Dost, M.T. (2005), “Öznel İyi Oluş Ölçeğinin Geliştirilmesi: Geçerlik ve Güvenirlik Çalışması”, Türk Psikolojik Danışma ve Rehberlik Dergisi, 3(23), 103-111.

Erdem, H., G. Kalkın, U. Türen, M. Deniz (2016), "Üniversite Öğrencilerinde Mobil Telefon Yoksunluğu Korkusunun (Nomofobi) Akademik Başarıya Etkisi”, Süleyman Demirel Üniversitesi İktisadi ve İdari Bilimler Fakültesi Dergisi, 21(3), 923-936.

Erdem, H., U. Türen, G. Kalkın (2017), "Mobil Telefon Yoksunluğu Korkusu (Nomofobi) Yayılımı: Türkiye'den Üniversite Öğrencileri ve Kamu Çalışanları Örneklemi”, Bilişim Teknolojileri Dergisi, 10(1), 1-12.

Gezgin, D.M., E. Şumuer, O. Arslan, S. Yıldırım (2017), "Nomophobia Prevalence among PreService Teachers: A Case of Trakya University", Trakya Üniversitesi Eğitim Fakültesi Dergisi, 7(1), 86-95.

González-Cabrera, J.U., A.U. León-Mejía, C.U. Pérez-Sancho, E. Calvete (2017), “Adaptation of the Nomophobia Questionnaire (NMP-Q) to Spanish in a Sample of Adolescents", Actas Esp Psiquiatr, 45(4), 137-144.

Ha, Y. M., W.J. Hwang (2014), “Gender Differences in Internet Addiction Associated with Psychological Health Indicators Among Adolescents Using A National Web-Based Survey", International Journal of Mental Health and Addiction, 12(5), 660-669.

Haug, S., R.P. Castro, M. Kwon, A. Filler, T. Kowatschve, M.P. Schaub (2015), "Smartphone Use and Smartphone Addiction Among Young People in Switzerland", Journal of behavioral Addictions, 4(4), 299-307.

Hills, P., M. Argyle (2002), "The Oxford Happiness Questionnaire: A Compact Scale for the Measurement of Psychological Well-Being", Personality and Individual Differences, 33(7), 1073-1082. 
Hoşgör, H., Ö. Tandoğan, D.G. Hoşgör (2017), "Nomofobinin Günlük Akıllı Telefon Kullanım Süresi ve Okul Başarısı Üzerindeki Etkisi: Sağlık Personeli Adayları Örneği”, Akademik Sosyal Araştırmalar Dergisi, 5(46), 573-595.

İlhan, T., Y. Özbay (2016), "Yaşam Amaçlarının ve Psikolojik İhtiyaç Doyumunun Öznel İyi Oluş Üzerindeki Yordayıcı Rolü”, Türk Psikolojik Danışma ve Rehberlik Dergisi, 4(34), 109-118.

Kang, S., J. Jung (2014), "Mobile Communication for Human Needs: A Comparison of Smartphone Use Between the U.S and Korea", Computers in Human Behavior, 35, 376-387.

Kim, J.H., M., Seo, P. David (2015), “Alleviating Depression Only to Become Problematic Mobile Phone Users: Can Face-To-Face Communication Be the Antidote?", Computers in Human Behavior, 51, 440-447.

King, A.L.S., A.M. Valença, A.C.O. Silva, T. Baczynski, M.R. Carvalho, A.E. Nardi (2013), "Nomophobia: Dependency on Virtual Environments or Social Phobia?", Computers in Human Behavior, 29(1), 140-144.

King, A.L.S., A.M.Valença, A.E. Nardi (2010), "Nomophobia: The Mobile Phone in Panic Disorder with Agoraphobia: Reducing Phobias or Worsening of Dependence?", Cognitive and Behavioral Neurology, 23(1), 52-54.

Kwon, M., J.Y. Lee, W.Y. Won, J.W. Park, J.A. Min, C. Hahn, X. Gu, J.H,Choi, D.J. Kim (2013), "Development and Validation of a Smartphone Addiction Scale (SAS)", PloS one, 8(2), 1-7.

Lee, S.Y. (2014), "Examining the Factors That Influence Early Adopters' Smartphone Adoption: The Case of College Students". Telematics and Informatics, 31(2), 308318.

Mail Online (2008), Nomophobia is the Fear of Being Out of Mobile Phone Contact-and it's The Plague of Our 24/7 Age, http://www.dailymail.co.uk/news/article550610/Nomophobia-fear-mobile-phone-contact--plague-24-7-age.html., E.T.: 02.02.2018.

Minaz, A., Ö. Çetinkaya Bozkurt (2017), “Üniversite Öğrencilerinin Akıllı Telefon Bağımlılık Düzeylerinin ve Kullanım Amaçlarının Farklı Değişkenler Açısından İncelenmesi”, Mehmet Akif Ersoy Üniversitesi Sosyal Bilimler Enstitüsü Dergisi, 9(21), 268-286.

Newport, F. (2015), Most U.S. Smartphone Owners Check Phone at Least Hourly, http://www.gallup.com/poll/184046/smartphone-owners-check-phone-leasthourly.aspx., E.T.: 15.02.2018.

Nikhita, C.S., P.R. Jadhav, S.A. Ajinkya (2015), "Prevalence of Mobile Phone Dependence in Secondary School Adolescents", Journal of Clinical and Diagnostic Research, 9(11), VC06-VC09.

Özaşçılar, M. (2012), “Genç Bireylerin Cep Telefonu Kullanımı ve Bireysel Güvenlik: Üniversite Öğrencilerinin Cep Telefonunu Bireysel Güvenlik Amaçl1 Kullanımları", Sosyoloji Araştırmaları Dergisi, 15(1), 43-74. 
Özgün, A., F. Yaşartürk, B. Ayhan T.Bozkuş (2017), "Hentbolcuların Spora Özgü Başarı Motivasyonu ve Mutluluk Düzeyleri Arasındaki İlişkinin İncelenmesi”, Uluslararası Kültürel ve Sosyal Araştırmalar Dergisi (UKSAD), 3(2), 83-94.

Park, N., Y.C. Kim, H.Y. Shon, H. Shim (2013), "Factors Influencing Smartphone Use and Dependency in South Korea", Computers in Human Behavior, 29(4), 1763-1770.

Pavithra, M.B., S. Madhukumar, M. Mahadeva (2015), "A Study on Nomophobia-Mobile Phone Dependence, among Students of a Medical College in Bangalore", National Journal of Community Medicine, 6(3), 340-344.

Salehan, M., A. Negahban (2013), "Social Networking on Smartphones: When Mobile Phones Become Addictive". Computers in Human Behavior, 29(6), 2632-2639.

SecurEnvoy (2012), 66\% of the Population Suffer From Nomophobia: The Fear of Being Without Their Phone, https://www.securenvoy.com/blog/2012/02/16/66-of-thepopulation-suffer-from-nomophobia-the-fear-ofbeing-without-their-phone/, E.T.: 10.02.2018

Sevi, O.M., G. Odabaşığlu, Y. Genç, İ. Soykal, Ö. Öztürk (2014), “Cep Telefonu Envanteri: Standardizasyonu ve Kişilik Özellikleriyle İlişkisinin İncelenmesi”, Bağımlılık Dergisi, 15(1), 15-22.

Süler, M. (2016), Akıllı Telefon Bă̆ımlılı̆̆ının Öznel Mutluluk Düzeyine Etkisinin Çeşitli Değişkenler Açısından İncelenmesi, Yayımlanmamış Yüksek Lisans Tezi, Sakarya: Sakarya Üniversitesi Eğitim Bilimleri Enstitüsü.

Şar, A.H., A. Işıklar (2012), "Problemli Mobil Telefon Kullanım Ölçeğinin Türkçeye Uyarlamas", International Journal of Human Sciences [Online], (9)2, 264-275.

Tavolacci, M.P., G. Meyrignac, L. Richard, P. Dechelotte, J. Ladner (2015), "Problematic Use of Mobile Phone and Nomophobia Among French College Studentsmarie-Pierre Tavolacci”, European Journal of Public Health, 25(3), 206.

Taylor, S.H., N.N. Bazarova (2018), Social Media and Subjective Well-Being: A Relational Perspective, in A Networked Self and Love, Routledge.

Türkiye İstatistik Kurumu (2016), Hanehalkı Bilişim Teknolojileri Kullanım Araştırması, http://www.tuik.gov.tr/PreTablo.do?alt_id=1028., E.T.: 27.01.2018.

Uysal, Ş., H. Özen, C. Madenoğlu (2016), "Social Phobia in Higher Education: The influence of Nomophobia on Social Phobia", The Global e-learning Journal, 5(2), 1-8.

Wood, W., N. Rhodesve, M. Whelan (1989), "Sex Differences in Positive Well-Being: A Consideration of Emotional Style and Marital Status", Psychological Bulletin, 106(2), 249-264.

Yildirim, C., E. Sumuer, M. Adnan, S. Yildirim (2016), "A Growing fear: Prevalence of Nomophobia among Turkish College Students", Information Development, 32(5), 1322-1331.

Yildirim, C., A.P. Correia (2015), "Exploring the Dimensions of Nomophobia: Development and Validation of a Self-Reported Questionnaire", Computers in Human Behavior, 49, 130-137.

Yoo, Y.S., O.H. Cho, K.S. Cha (2014), "Associations Between Overuse of the Internet and Mental Health in Adolescents", Nursing \& Health Sciences, 16(2), 193-200. 